\author{
Asian Journal of \\ Medical and Biological Research \\ ISSN 2411-4472 (Print) 2412-5571 (Online) \\ www.ebupress.com/journal/ajmbr
}

\title{
Article \\ Effects of medicinal plants, Alisma canaliculatum, Laminaria japonica and Cornus officinalis, treated with probiotics on growth performance, meat composition and internal organ development of broiler chicken
}

\author{
Md. Sazedul Karim Sarker ${ }^{1,2}$, Gwi-Man Kim², Farhana Sharmin ${ }^{3}$ and Chul-Ju Yang ${ }^{2} *$ \\ ${ }^{1}$ Poultry Production Research Division, Bangladesh Livestock Research Institute, Savar, Dhaka 1341, \\ Bangladesh \\ ${ }^{2}$ Department of Animal Science \& Technology, Sunchon National University, Jeonnam, Suncheon city, \\ Republic of Korea \\ ${ }^{3}$ Department of Food Science \& Technology, Sunchon National University, Jeonnam, Suncheon city, Republic \\ of Korea
}

*Corresponding author: Professor Dr. Chul-Ju Yang, Department of Animal Science and Technology, Sunchon National University, Jeonnam, Suncheon city, Republic of Korea. E-mail: yangcj@scnu.kr

Received: 07 December 2016/Accepted: 22 December 2016/ Published: 29 December 2016

\begin{abstract}
A trial was conducted with 175 day old Ross broiler chicks to evaluate the effectiveness of Alisma canaliculatum (Water plantain or Theksa), Laminaria japonica (Sea tangle or Dashima) and Cornus officinalis (Cornelain cherry or Sansuyu) medicinal plants treated with probiotics in replacing antibiotic. Three medicinal plants were prepared in dry and flour form with treatment of probiotics. The groups were control (basal diet), antibiotic (basal diet $+0.05 \%$ OTC, oxytetracycline), Water plantain treated with Probiotics (WPP) $0.5 \%$, Sea tangle treated with Probiotics (STP) $0.5 \%$ and Cornelian cherry treated with Probiotics (CCP) $0.5 \%$ in basal diet. The broilers were distributed in a completely randomized design having 5 replications with 7 chicks per replication in wire cage. The data were analyzed by SAS package program. Addition of three medicinal plants in broiler diets didn't show negative effect on growth and feed conversion efficiency in broilers. Significantly highest protein percentage in broiler meat was found in groups fed the three medicinal plants treated with probiotics (WPP, STP and CCP) compared with other groups $(\mathrm{P}<0.05)$. Crude ash also increased significantly by the three medicinal plants addition compared to control especially in breast meat $(\mathrm{P}<0.05)$. Addition of probiotics treated with medicinal plants had similar beneficial effects on most of the observed parameters to those found in antibiotic-fed groups, so it implies that these three medicinal plants can be the possible alternatives to antibiotic for broiler production.
\end{abstract}

Keywords: Alisma canaliculatum probiotics; Laminaria japonica probiotics; Cornus officinalis probiotics; oxytetracycline (OTC); growth performance, internal organ weight; broiler chick

\section{Introduction}

Antibiotic usage has facilitated the efficient production of poultry, allowing the consumer to purchase, at a reasonable cost, high quality meat and eggs. Antibiotic usage has also enhanced the health and well-being of poultry by reducing the incidence of disease. Despite many benefits brought by antibiotic usage, unfortunately consumer perceptions are dominant that edible poultry tissues are contaminated with harmful concentrations of drug residues (Donoghue, 2003). In a consumer survey, Resurreccion and Galvez (1999) reported that $77 \%$ of consumers responding considered animal drug residues in meats to be an extreme health concern and the remaining $23 \%$ responding thought that drug residues were not a problem. 
A growing body of scientific research supports the role of probiotics as effective alternatives to the use of AGP (antibiotic growth promoter) in animal nutrition (Ghadban, 2002; Patterson and Burkholder, 2003). In this sense, probiotics, classified as zootechnical feed additives (European Commission, 2003), comprise a functional nutritional approach, whereby maintenance of a healthy gastrointestinal (GI) environment and improved intestinal function is pursued through the intake of adequate quantities of live beneficial microorganisms (Fuller, 1989; FAO/WHO, 2002). It is becoming increasingly evident that to achieve the aims above and to significantly reduce the use of antibiotics, a combination of intervention strategies such as genetic selection of resistant animals, sanitation practices, elimination of pathogens from feed and water, vaccinations, and applications of suitable feed and water additives (Doyle and Erickson, 2006) is required. In this study, three medicinal plants were used with multi-probiotics (Lactobacillus acidophilus KCTC 3111, Lactobacillus plantarum KCTC 3104, Bacillus subtilis KCTC 3239 and Saccharomycetes cerevisiae KCTC 7915) for using as feed additives to substitute antibiotic. The combination of different additives might have synergistic effect on improving meat quality which was already revealed by the recent studies (Sarker et al., 2010a, 2010b; Gallaher and Khil, 1999; Awad et al., 2009).

Theksa (Alisma canaliculatum) is a kind of harmless anti-mutational plant which suppresses DNA damage and also has cholesterol lowering activities.

Dashima (Laminaria japonica) is called Dashima in Korean, Kombu in Japanese and Haidai in Chinese. It is also known as edible kelp from the family Laminariaceae widely eaten in East Asia. The active component contained in this brown seaweed is fucoxanthin. Cornus officinalis is a species of dogwood known also as Japanese cornelian cherry. In Korean it is known as sansuyu, in Chinese as shan zhu yu and in Japanese as sanshuyu. It is used as a food plant and as a medicinal plant. The fruit has an antibacterial action, inhibiting the growth of Bacillus dysenteriae and Staphylococcus (Yeung, 1985). The plant is antibacterial, diuretic, hypotensive and a urinary antiseptic (Duke and Ayensu, 1985).

The combination effects of a medicinal plant product and multi-probiotics on the proper internal organ development is associated with their growth promoting efficiency and carcass quality of broilers is still unclear. So the present study was designed to access the broiler growth performance, chemical composition of meat, and internal organ weight in contrast with control and antibiotic-fed birds.

\section{Materials and Methods}

\subsection{Animals and experimental design}

One hundred seventy five 1-day old "Ross" broiler chicks were considered for this study. The chicks were housed in a close, ventilated caged-broiler house in which they were raised for 24 hours of daily light. From 1 to 14 days of age, supplemental heat was provided by electric heater which was placed inside the chicken house, thereafter the room temperature was kept at $22 \pm 2^{\circ} \mathrm{C}$ through a supplemental heating system. The birds were assigned to 5 treatments with 5 replications following completely randomized design (CRD). There were five dietary treatments, control, antibiotic (basal $+0.05 \%$ oxytetracycline), $0.5 \% \mathrm{TP}, 0.5 \% \mathrm{DP}$ and $0.5 \% \mathrm{SP}$ with basal diet. The feed and drinking water were provided ad libittum to the broilers.

\subsection{Experimental diets and feeding}

Experimental diets were divided into two phases; starter 0-3 weeks and finisher 4-5 weeks of age. The diets were formulated following the recommendation of the National Research Council, NRC (1994) and are shown in Table 1. The probiotics used in the formulation of Alisma canaliculatum, Laminaria japonica and Cornus officinalis medicinal plants in replacing antibiotic are given in Table 2.

\subsection{Body weight gain, feed intake, FCR and mortality}

Body weights were measured on weekly basis from initial day to the final day of the experiment. Feed intake had been determined by measuring feed residue on weekly basis since the beginning of the experiment. Feed conversion ratio was obtained by dividing the feed intake by body weight gain. Dead birds were recorded and accordingly adjusted the feed intake.

\subsection{Carcass composition and organ development}

At the end of the experiment, 20 chickens were slaughtered and samples were collected from breast and thigh muscle. Percentage of moisture, protein, fat, and ash content was determined in meat samples according to the Association of Official Analytical Chemists (AOAC, 1990). The organ development was measured by taking weight and length of the broilers after slaughtering and calculated in respect of body weight. 


\subsection{Statistical analysis}

The data obtained from this study were analyzed by General Linear Models (GLM) of SAS Package Program (1990) to estimate variance components for a completely randomized design. Duncan's Multiple Comparison Tests (1955) were used to examine significant differences between treatment means. Differences were statistically assessed at $\mathrm{P}<0.05$.

\section{Results and Discussion}

\subsection{Growth performance}

The results shown in Table 3 are body weight gain and feed intakes of broiler chicks although they were not significant among the treatment groups. These results are in agreement with the findings with our previous studies where same probiotics were used but with different medicinal plants (Sarker et al., 2010a; 2010b). This finding disagrees with Ryu et al. (2003), who observed that supplementation of 0.1 to $0.3 \%$ mixed probiotics containing Lactobacillus acidophilus, Bacillus subtilis and Saccharmyces cervisae to broiler diets improved weight gain and feed intake as well as feed conversion ratio. It appears that probiotics with mushroom extract offered no combination potential for weight gain, which was compromised in this study, but possible healthenhanced attributes (Willis et al., 2007). Addition of antibiotic and three probiotics in all groups reduced mortality compared to control group (Table 2). The trend of mortality revealed indirectly the potentiality of the medicinal plants treated with probiotics in the diet, in other sense, the immunomodulatory effect of the medicinal plant, as observed by Meng et al., (2006).

\subsection{Breast and thigh meats amount}

The amount of breast and thigh meat in freshly slaughtered broilers was calculated and the results are summarized in Table 4. Lowest breast meat percentage was recorded in CCP-fed group compared to control and antibiotic group $(\mathrm{P}<0.05)$, although there were no statistical differences observed within the medicinal plantsfed groups.

\subsection{Proximate composition of meat}

Proximate analysis of the breast and thigh muscle of broiler meat is presented in Table 5. Moisture contents in breast meat in control and antibiotic group showed significantly higher values than other three groups $(\mathrm{P}<0.05)$, but no significant differences were observed in thigh meat moisture contents among probiotics-fed groups. Among the treatments considered, the lowest crude protein contents of breast muscle were found in control and antibiotics groups compared to other dietary feed additives group $(\mathrm{P}<0.05)$, whereas no statistical differences were observed in protein content of breast muscle $(\mathrm{P}>0.05)$ among the probiotic-fed treatments. Crude fat contents of breast and thigh meat were not influenced by addition of all feed additives including antibiotic. Crude ash contents of breast meat in theksa and sansuyu probiotics fed broilers were significantly higher than Dashima probiotics, control and antibiotic groups. In case of thigh meat, crude ash content in dashima probiotics-treated groups showed significantly higher value than sansuyu probiotics-treated groups. While, there were no differences among control, antibiotic, WPP and CCP fed groups.

\subsection{Internal organ weight}

\subsubsection{Absolute weight of organs}

In Table 6, the kidney weight in CCP-fed group (13.21g) significantly was heavier compared to WPP-fed group $(10.16 \mathrm{~g})$ but similar to antibiotic-fed group (12.92g). Kidney weight in STP-fed group (11.43g) showed similarity to control $(11.16 \mathrm{~g})$. The spleen weight was higher in antibiotic- fed group $(1.57 \mathrm{~g})$ compared to control $(1.01 \mathrm{~g})$ and sansuyu probiotic groups $(0.96 \mathrm{~g})$. The WPP $(1.22 \mathrm{~g})$ and dashima probiotic $(1.28 \mathrm{~g})$ groups showed similar values, which were placed between control and antibiotic-fed groups. In addition, the absolute weights of crop, heart, liver, gizzard, pancreas, cecum, small intestine, large intestine, abdominal fat and proventriculus did not show any significant differences among the dietary treatment groups.

\subsubsection{Relative weight of organs percentage}

In Table 7, the weight of spleen relative to the BW in antibiotic-fed birds $(0.08 \%)$ showed significantly higher than control group $(0.05 \%)$ and CCP $(0.05 \%)$ fed birds $(\mathrm{P}<0.05)$. The relative spleen weights in Water plantain and Cornelian Cherry probiotics fed birds tended to be greater compared with control $(0.05 \%)$ without statistical differences. In addition, the relative weights of crop, heart, liver, gizzard, pancreas, cecum, small intestine, large intestine, abdominal fat and proventriculus remained unaffected by dietary treatment groups. 
Table 1. Feed ingredients and chemical composition of the basal diets for broiler starter and finisher.

\begin{tabular}{|c|c|c|}
\hline Ingredient(g/kg, as fed basis) & Starter (1 3) & Finisher (4 5) \\
\hline Corn grain & 57.67 & 60.14 \\
\hline Soybean meal & 26.50 & 25.40 \\
\hline Corn gluten & 5.00 & 4.20 \\
\hline Soybean oil & 2.20 & 1.50 \\
\hline Animal fats & 4.50 & 5.00 \\
\hline Salt & 0.25 & 0.25 \\
\hline Dicalcium Phosphate & 2.14 & 2.00 \\
\hline Limestone & 0.92 & 0.88 \\
\hline Vit-Min. premix ${ }^{1)}$ & 0.30 & 0.30 \\
\hline Choline & 0.08 & 0.07 \\
\hline L-lysine & 0.24 & 0.16 \\
\hline Methionine & 0.20 & 0.10 \\
\hline Total & 100.00 & 100.00 \\
\hline \multicolumn{3}{|l|}{ Chemical composition $^{2)}$} \\
\hline $\mathrm{ME}(\mathrm{MJ} / \mathrm{kg})$ & 3100.00 & 3150.00 \\
\hline Crude protein $(\mathrm{g} / \mathrm{kg})$ & 22.00 & 19.00 \\
\hline Crude fat $(\mathrm{g} / \mathrm{kg})$ & 4.00 & 4.50 \\
\hline Crude ash (g/kg) & 8.0 & 8.00 \\
\hline Crude fiber $(\mathrm{g} / \mathrm{kg})$ & 6.00 & 6.00 \\
\hline Methionine $(\mathrm{g} / \mathrm{kg})$ & 0.79 & 0.70 \\
\hline $\mathrm{Ca}(\mathrm{g} / \mathrm{kg})$ & 0.80 & 0.75 \\
\hline $\mathrm{P}(\mathrm{g} / \mathrm{kg})$ & 0.54 & 0.52 \\
\hline
\end{tabular}

${ }^{1)}$ Vit-min. mix. provided following nutrients per kg of diet : Vitamin A, 9,000,000 IU; Vitamin D3, 2,100,000 IU; Vitamin E, 15,000 IU; Vitamin K, 2,000 mg; Vitamin B1, 1,500 mg ;Vitamin B2, 4,000 mg; Vitamin B6, 3,000 mg; Vitamin B12, 15 mg,; Pan-Acid-Ca, 8500 mg; Niacin, 20,000 mg; Biotin, 110 mg; Folic-Acid, 600 mg; Co, 300 mg; Cu, 3,500 mg; Mn, 55,000 mg; Zn, 40,000 mg; I, 600 mg; Se, 130 mg

${ }^{2)}$ Calculated values

Table 2. Name and number of microflora used for fermentation of theksa, dashima and sansuyu plant.

\begin{tabular}{llll}
\hline Microflora and Strain & Isolation source & Content $(\mathbf{c f u} / \mathbf{g})$ & Optimum temp. $\left({ }^{\circ} \mathrm{C}\right)$ \\
\hline $\begin{array}{l}\text { Lactobacillus acidophilus } \\
\text { (KCTC 3111) }\end{array}$ & Human feces & $4.2 \times 10^{7}$ & 37 \\
$\begin{array}{l}\text { Lactobacillus plantarum } \\
\text { (KCTC 3104) }\end{array}$ & Packled cabbage & $5.8 \times 10^{6}$ & 37 \\
$\begin{array}{l}\text { Bacillus subtilis } \\
\text { (KCTC 3239) }\end{array}$ & - & $2.6 \times 10^{7}$ & 30 \\
Saccharomycetes cerevisiae (KCTC 7915) & Gebruder Mayer yeast & $6.2 \times 10^{9}$ & 30 \\
\hline
\end{tabular}

KCTC: Korean Collection for Type Cultures; HEP: Hamcho and Eosungcho Probiotics

Table 3. Effect of probiotics with different medicinal plants on the growth performance in broiler.

\begin{tabular}{lllllll}
\hline Parameters & \multirow{2}{*}{ Control } & Antibiotic & $\begin{array}{l}\text { WPP } \\
\mathbf{0 . 5 \%}\end{array}$ & $\begin{array}{l}\text { STP } \\
\mathbf{0 . 5 \%}\end{array}$ & $\begin{array}{l}\text { CCP } \\
\mathbf{0 . 5 \%}\end{array}$ & SEM \\
\hline Initial weight (g) & 41.11 & 41.80 & 41.86 & 40.49 & 41.14 & 0.47 \\
Final weight (g) & 1930.29 & 1920.57 & 1981.71 & 1885.14 & 1875.43 & 42.69 \\
Weight gain (g) & 1889.17 & 1878.77 & 1939.86 & 1844.66 & 1834.29 & 42.64 \\
Feed intake (g) & 3144.73 & 3021.69 & 3252.37 & 3055.31 & 3110.06 & 85.21 \\
FCR (feed/gain) & $1.66^{\mathrm{a}}$ & $1.61^{\mathrm{b}}$ & $1.68^{\mathrm{a}}$ & $1.65^{\mathrm{ab}}$ & $1.69^{\mathrm{a}}$ & 0.01 \\
Mortality (\%) & 5.71 & 2.85 & 2.85 & 2.85 & 2.85 & - \\
\hline
\end{tabular}

SEM: Standard error of mean, OTC: Oxytetracycline, WPP: Water Plantain treated with Probiotics, STP: Sea Tangle treated with Probiotics, CCP: Cornelian Cherry treated with Probiotics.

${ }^{\mathrm{a}, \mathrm{b}}$ Within the same row, means with different superscripts are significantly different $(\mathrm{P}<0.05$, ANOVA, Duncan's test $)$. 
Table 4. Effect of probiotics with different medicinal plants on the breast and thigh meat in broiler.

\begin{tabular}{lllllll}
\hline Parameters & Control & Antibiotic & $\begin{array}{l}\text { WPP } \\
\mathbf{0 . 5 \%}\end{array}$ & $\begin{array}{l}\text { STP } \\
\mathbf{0 . 5 \%}\end{array}$ & $\begin{array}{l}\text { CCP } \\
\mathbf{0 . 5 \%}\end{array}$ & SEM \\
\hline Body weight (g) & 1875.00 & 1960.00 & 1895.00 & 1810.00 & 1875.00 & 80.50 \\
Absolute breast meat wt. (g) & 284.50 & 294.50 & 267.00 & 258.25 & 259.00 & 13.73 \\
Breast meat (\%) & $15.17^{\mathrm{a}}$ & $14.80^{\mathrm{ab}}$ & $14.09^{\mathrm{bc}}$ & $14.27^{\mathrm{bc}}$ & $13.81^{\mathrm{c}}$ & 0.24 \\
Absolute thigh meat wt. (g) & $355.50^{\mathrm{ab}}$ & $390.00^{\mathrm{a}}$ & $382.00^{\mathrm{ab}}$ & $336.00^{\mathrm{b}}$ & $341.25^{\mathrm{ab}}$ & 15.08 \\
Thigh meat (\%) & 18.96 & 19.60 & 20.16 & 18.56 & 18.20 & 0.57 \\
\hline
\end{tabular}

SEM: Standard error of mean

a,b Values with different superscripts in the same row differ significantly ( $\mathrm{P}<0.05$, ANOVA, Duncan's test)

Table 5. Effect of probiotics with different medicinal plants on the breast and thigh meat composition in broiler.

\begin{tabular}{lllllll}
\hline Parameters & Control & Antibiotic & $\begin{array}{l}\text { WPP } \\
\mathbf{0 . 5 \%}\end{array}$ & $\begin{array}{l}\text { STP } \\
\mathbf{0 . 5 \%}\end{array}$ & $\begin{array}{l}\text { CCP } \\
\mathbf{0 . 5 \%}\end{array}$ & SEM \\
\hline Breast meat & & & & & & \\
Moisture & $73.84^{\mathrm{a}}$ & $73.77^{\mathrm{a}}$ & $71.94^{\mathrm{b}}$ & $70.97^{\mathrm{b}}$ & $71.48^{\mathrm{b}}$ & 0.43 \\
Crude protein & $24.65^{\mathrm{b}}$ & $24.48^{\mathrm{b}}$ & $26.39^{\mathrm{a}}$ & $27.37^{\mathrm{a}}$ & $26.56^{\mathrm{a}}$ & 0.44 \\
Crude fat & 0.26 & 0.50 & 0.24 & 0.34 & 0.46 & 0.07 \\
Crude ash & $1.25^{\mathrm{c}}$ & $1.25^{\mathrm{c}}$ & $1.43^{\mathrm{ab}}$ & $1.32 \mathrm{~b}^{\mathrm{c}}$ & $1.51^{\mathrm{a}}$ & 0.04 \\
Thigh meat & & & & & & \\
Moisture & 74.50 & 75.54 & 75.96 & 75.91 & 75.78 & 0.41 \\
Crude protein & 23.61 & 22.62 & 22.31 & 22.26 & 22.67 & 0.15 \\
Crude fat & 0.62 & 0.66 & 0.55 & 0.55 & 0.41 & 0.04 \\
Crude ash & $1.27^{\mathrm{ab}}$ & $1.18^{\mathrm{ab}}$ & $1.19^{\mathrm{ab}}$ & $1.28^{\mathrm{a}}$ & $1.14^{\mathrm{b}}$ & 0.43 \\
\hline
\end{tabular}

SEM: Standard error of mean, OTC: Oxytetracycline

WPP: Water Plantain treated with Probiotics, STP: Sea Tangle treated with Probiotics, CCP: Cornelian Cherry treated with Probiotics.

${ }^{\mathrm{a}, \mathrm{b}}$ Values with different superscripts in the same row differ significantly $(\mathrm{P}<0.05)$

Table 6. Effect of different feed additives on the absolute internal organ weights of broilers (g).

\begin{tabular}{lllllll}
\hline Parameters & Control & Antibiotic & $\begin{array}{l}\text { WPP } \\
\mathbf{0 . 5 \%}\end{array}$ & $\begin{array}{l}\text { STP } \\
\mathbf{0 . 5 \%}\end{array}$ & $\begin{array}{l}\text { CCP } \\
\mathbf{0 . 5 \%}\end{array}$ & SEM \\
\hline Body wt & 1875.00 & 1990.00 & 1875.00 & 1895.00 & 1810.00 & 80.50 \\
Crop wt & 6.80 & 5.99 & 7.18 & 6.01 & 6.49 & 0.72 \\
Heart wt & 10.49 & 9.49 & 9.96 & 9.56 & 9.37 & 0.75 \\
Liver wt & 37.28 & 41.24 & 39.12 & 40.60 & 39.38 & 2.47 \\
Gizzard wt & 20.16 & 20.09 & 19.46 & 17.18 & 17.03 & 1.51 \\
Pancreas wt & 3.51 & 3.52 & 3.96 & 4.09 & 3.64 & 0.23 \\
Cecum wt & 5.96 & 6.22 & 7.45 & 6.24 & 7.58 & 1.02 \\
Kidney wt & $11.16^{\mathrm{ab}}$ & $12.92^{\mathrm{a}}$ & $10.16^{\mathrm{b}}$ & $11.43^{\mathrm{ab}}$ & $13.21^{\mathrm{a}}$ & 0.66 \\
Small intestine wt & 46.37 & 44.73 & 46.15 & 44.94 & 46.41 & 3.34 \\
Large intestine wt & 2.60 & 2.79 & 2.83 & 2.40 & 2.36 & 0.30 \\
Abdominal fat wt & 28.50 & 34.96 & 26.19 & 36.40 & 26.52 & 4.25 \\
Proventriculus wt & 7.63 & 7.07 & 6.57 & 5.89 & 5.51 & 0.61 \\
Spleen wt & $1.01^{\mathrm{b}}$ & $1.57^{\mathrm{a}}$ & $1.22^{\mathrm{ab}}$ & $1.28^{\mathrm{ab}}$ & $0.96^{\mathrm{b}}$ & 0.15 \\
\hline
\end{tabular}

SEM: Standard error of mean

WPP: Water Plantain treated with Probiotics, STP: Sea Tangle treated with Probiotics, CCP: Cornelian Cherry treated with Probiotics.

${ }^{a, b, c}$ Values with different superscripts in the same row differ significantly $(\mathrm{P}<0.05)$

*Absolute wt.: Average organ weight of 4 broilers in each group immediately after slaughter in $\mathrm{g}$ 
Asian J. Med. Biol. Res. 2016, 2 (4)

Table 7. Effect of different feed additives on the relative internal organ weights to $\mathrm{BW}$ of broiler chickens (\%).

\begin{tabular}{lllllll}
\hline Parameters & Control & Antibiotic & $\begin{array}{l}\text { WPP } \\
\mathbf{0 . 5 \%}\end{array}$ & $\begin{array}{l}\text { STP } \\
\mathbf{0 . 5 \%}\end{array}$ & $\begin{array}{l}\text { CCP } \\
\mathbf{0 . 5 \%}\end{array}$ & SEM \\
\hline Crop wt & 0.33 & 0.29 & 0.35 & 0.29 & 0.31 & 0.04 \\
Heart wt & 0.51 & 0.46 & 0.48 & 0.46 & 0.46 & 0.04 \\
Liver wt & 1.81 & 2.00 & 1.90 & 1.97 & 1.91 & 0.12 \\
Gizzard wt & 0.98 & 0.98 & 0.94 & 0.83 & 0.83 & 0.07 \\
Pancreas wt & 0.17 & 0.17 & 0.19 & 0.20 & 0.18 & 0.01 \\
Cecum wt & 0.29 & 0.30 & 0.36 & 0.30 & 0.37 & 0.05 \\
Kidney wt & $0.54^{\mathrm{ab}}$ & $0.63^{\mathrm{a}}$ & $0.49^{\mathrm{b}}$ & $0.55^{\mathrm{ab}}$ & $0.64^{\mathrm{a}}$ & 0.03 \\
Small intestine wt & 2.25 & 2.17 & 2.24 & 2.18 & 2.25 & 0.16 \\
Large intestine wt & 0.13 & 0.14 & 0.14 & 0.12 & 0.11 & 0.01 \\
Abdominal fat wt & 1.38 & 1.70 & 1.27 & 1.77 & 1.29 & 0.21 \\
Proventriculus wt & 0.37 & 0.34 & 0.32 & 0.29 & 0.27 & 0.03 \\
Spleen wt & $0.05^{\mathrm{b}}$ & $0.08^{\mathrm{a}}$ & $0.06^{\mathrm{ab}}$ & $0.06^{\mathrm{ab}}$ & $0.05^{\mathrm{b}}$ & 0.01 \\
\hline
\end{tabular}

SEM: Standard error of mean

WPP: Water Plantain treated with Probiotics, STP: Sea Tangle treated with Probiotics, CCP: Cornelian Cherry treated with Probiotics.

${ }^{a, b, c}$ Values with different superscripts in the same row differ significantly $(\mathrm{P}<0.05)$

*Relative wt.: Percent average organ weight of 4 broilers in respect of live body weight

\section{Conclusions}

Although no significant differences were observed in body weight gain among all treatment groups but highest protein percentage in broiler meat was found in probiotic-fed groups (WPP, STP and CCP) among all treatment groups $(\mathrm{P}<0.05)$. Crude ash was significantly higher in groups offered with antibiotics and three probiotics with different medicinal plants compared to control, especially in breast meat $(\mathrm{P}<0.05)$. No remarkable negative effects were recorded in absolute and relative organ weights of broilers fed probiotics with medicinal plants. Addition of probiotics with medicinal plants was validated to have beneficial effects on most of the observed parameters in this study, especially in WPP and STP-fed broilers, hence it could be concluded that these medicinal plants can be the possible alternative to antibiotic for broiler production.

\section{Conflict of interest}

None to declare.

\section{References}

Awad WA, K Chareeb, S Abdel-Raheem and J Bohm, 2009. Effects of dietary inclusion of probiotic and symbiotic on growth performance, organ weight and intestinal histomorphology of broiler chickens. Poult Sci., 88:49-56.

Donoghue DJ, 2003. Antibiotic residues in poultry tissues and eggs: Human health concerns? Poult. Sci., 82:618-621

Doyle MP and MC Erickson, 2006. Reducing the carriage of foodborne pathogens in livestock and poultry. Poult. Sci., 85:960-973.

Duke JA and ES Ayensu, 1985. Medicinal plants of China- reference publications, Inc. ISBN 0-917256-20-4

European Commission, 2003. Regulation (EC) No. 1831/2003 of the European Parliament and of the Council on additives for use in animal nutrition. 22 September. Official Journal of the European Union L 268/29.

FAO/WHO, 2002. Working group report on drafting guidelines for the evaluation of probiotics in food. 30 April-1 May, London, UK and Ontario, Canada. FAO, Rome, Italy.

Fuller R, 1989. Probiotics in man and animals. J. Appl. Bacteriol., 66:365-378.

Gallaher DD and J Khil, 1999. The effect of synbiotics on colon carcinogenesis in rats. J. Nutr., 129:1483-1487.

Ghadban GS, 2002. Probiotics in broiler production-A review. Arch. Geflugelkd., 66:49-58.

Meng L, Y Lozano, I Bombarda, E Gaydou and BLi, 2006. Anthocyanin and flavonoid production from Perilla frutescens: Pilot plant scale processing including Cross-Flow Microfiltration and Reverse Osmosis. J. Agric. Food Chem., 54: 4297-4303.

NRC, 1994. Nutrient Requirements of Poultry. 9th rev. ed. Natl. Acad. Sci., Washington, DC. 
Patterson JA, and KM Burkholder, 2003. Application of prebiotics and probiotics in poultry production. Poult. Sci., 82:627-631.

Resurreccion AVA, and FCF Galvez,1999. Will consumers buy irradiated beef? Food Technol., 53:52-55.

Ryu KS, WJ Shin, JH Park, MS Ryu, JS Kim , SH Kim , HL Li, , 2003. Impact of feeding multiple probiotics on performance and intestinalmicroflora in broiler chicks. J. Anim. Sci. Technol. (Korea), 30: 197-202

Sarker MSK, SR Park, GM Kim and CJ Yang, 2010a. Hamcho (Salicornia herbacea) with probiotics as alternative to antibiotic for broiler Production. J. Med. Plants Res., 4: 415-420.

Sarker MSK, SY Ko, GM Kim and CJ Yang. 2010b. Effects of Camellia sinensis and mixed probiotics on the growth performance and body composition in broiler. J. Med. Plants Res., 4: 546-550.

TsukuiT, K Konno, M Hosokawa, H Maeda, T Sashima and KMiyashita, 2007. Fucoxanthin and fucoxanthinol enhance the amount of docosahexaenoic acid in the liver of KKAy obese/diabetic mice. J. Agric. Food Chem., 55: 5025-9.

Willis WL, OS Isikhuemhen and SA Ibrahim, 2007. Performance assessment of broiler chickens given mushroom extract alone or in combination with probiotics. Poult. Sci., 86: 1856-1860

Yeung HC, 1985. Handbook of Chinese herbs and formulas. Institute of Chinese Medicine, Los Angeles. 